Original Research

\title{
Experimental Investigation into Disturbance of Ca-Mg Equilibrium and Consequences for Charophytes after Iron and Aluminium Coagulants Application
}

\author{
Michał Rybak $^{1}$, Tomasz Joniak ${ }^{1 *}$, Tadeusz Sobczyński² \\ ${ }^{1}$ Department of Water Protection, Institute of Environmental Biology, Faculty of Biology, \\ Adam Mickiewicz University, Poznań \\ ${ }^{2}$ Department of Analytical Chemistry, Faculty of Chemistry, Adam Mickiewicz University, Poznań, Poland
}

Received: 13 Febrary 2018

Accepted: 18 April 2018

\begin{abstract}
Iron sulphate and polyaluminum chloride are commonly used in water restoration to eliminate cyanobacteria bloom and improve water quality. Nevertheless, the influence of coagulants on water organisms remains insufficiently studied. The study involves the analysis of phosphate coagulants' impact on calcium and magnesium concentrations in the Chara hispida community. The experiments were carried out in field mesocosms. Both coagulants were applied once in three different doses: 50.0, 100.0 , and $200.0 \mathrm{~cm}^{3} \cdot \mathrm{m}^{-3}$. The application of coagulants caused a decrease of $\mathrm{pH}$ and calcium carbonate and magnesium carbonate dissolution. Although the changes were proportional to the coagulant concentrations, the aluminum coagulant triggered more considerable disturbances. The highest dose of iron sulphate caused the precipitation of hardly soluble calcium sulphate and the elimination of part of calcium from biological circulation. The concentrations of magnesium in water increased only at $\mathrm{pH}<4.5$ following the application of the highest dose of polyaluminum chloride. Shifts in the $\mathrm{Ca}-\mathrm{Mg}$ equilibrium, which result in the disturbance of biogenic calcification, may affect charophyte metabolism and lead to the elimination of charophyte communities. Therefore, inactivation treatments using acidic coagulants in lakes with charophyte communities ought to be preceded by preliminary studies in order to determine the least harmful dosage for the ecosystem.
\end{abstract}

Keywords: charophyte encrustation, $\mathrm{Ca}-\mathrm{Mg}$ equilibrium, chemical phosphate coagulants, acidification, lake restoration

*e-mail: tjoniak@amu.edu.pl 


\section{Introduction}

Charophytes contribute to maintaining a clear water state by producing large quantities of biomass and accumulating large concentrations of nutrients on the one hand, and competing with phytoplankton in resources on the other [1-2]. They stabilize bottom sediments, limit the migration of nutrients, and create refugium and food base for animals [3]. Moreover, the water decalcification process is followed by co-precipitation of phosphates with calcite, resulting in reduced phosphorus bioavailability in water [4-5].

Despite the fact that charophytes are supposed to be a typical component of clear, alkaline, and nutrient-poor lakes, some species also inhabit meso-eutrophic and eutrophic water bodies [6-7]. These types of lakes are more vulnerable to restoration treatments when taking into account an urgent need to implement the guidelines of the Water Framework Directive. Furthermore, occasionally some restoration treatments are carried out in lakes with temporary trophic disturbances, which is most often correlated with phytoplankton blooms and shifts in physicochemical features of water [8-9]. One of the most common methods of restoration is the chemical inactivation of phosphates. Usually this is undertaken prior to or complementary to active biological and physical methods, e.g., wind aeration [10-11]. This method is based on the precipitation of phosphates to the bottom sediments after binding with iron or aluminium acid coagulant [12]. These metals, added to water, create with mineral phosphates salts, which undergo precipitation and sedimentation. Finally, aggregate-flocs are formed with a large absorptive surface as a result of coagulation and flocculation processes [13]. Although this process is very effective, acidification poses a threat to hydrobiota [14].

The hardness of water mainly depends on the presence of bivalent cations that are naturally present in water and follows features of the catchment as well the chemical composition of watercourses in the case of lakes [15]. Calcium $\left(\mathrm{Ca}^{2+}\right)$ and magnesium $\left(\mathrm{Mg}^{2+}\right)$ are the main elements that influence water hardness as well as affect the buffer capacity of lakes and regulate their biological productivity. A higher concentration of calcium and magnesium cations is vital for many organisms, especially the algae from the Chlorophyta, Rhodophyta, Phaeophyceae, and Chrysophyceae [16]. Thalli of these organisms is covered by calcium and/or magnesium carbonate, which is related to photosynthetic activity. This is a consequence of changes in $\mathrm{pH}$ caused by the use of hydrogencarbonate $\left(\mathrm{HCO}_{3}^{-}\right)$as an alternative to carbon dioxide $\left(\mathrm{CO}_{2}\right)$ during photosynthesis. As a result, insoluble calcium and/ or magnesium carbonate is deposited on the surface thalli, producing encrustation [16]. In this way, easily soluble calcium hydrocarbonate is transformed into hardly soluble calcium carbonate (1). An analogous process occurs during the transformation of magnesium hydrocarbonate into magnesium carbonate [17-18].
Encrustation is affected by various factors, such as $\mathrm{pH}$ of water, temperature, calcium, magnesium, and carbonate ions concentration as well as by plant age and photosynthetic activity [19].

$$
\mathrm{Ca}\left(\mathrm{HCO}_{3}\right)_{2} \leftrightarrow \mathrm{CaCO}_{3} \downarrow+\mathrm{H}_{2} \mathrm{CO}_{3}
$$

Charophytes (Characeae, Chlorophyta) as the most encrusted group of algae, produce internal incrustation and external encrustations on the surfaces of cell walls and, in some species, organic-matrix-mediated calcification within the walls of the oogonium [5, 20]. Due to tight adherence to the thalli (unlike vascular plants), the encrustation fortifies the cell structure, increasing the resistance to mechanical injuries and protecting it from UV radiation [16, 21]. In the case of the most common genus, Chara, it is supposed that the increase of photosynthetic activity results in an increase in water decalcification [22].

Due to the chemical features of coagulants, their introduction to a lake causes changes in the physical and chemical properties of water. These disturbances may directly and indirectly influence the macrophyte and charophyte communities [23-24]. It has been hypothesized that chemical coagulants cause water acidification, which changes alkaline conditions preferred by charophytes and dissolves charophyte encrustation. The aim of the study was an analysis of the scale and direction of changes in calcium and magnesium concentrations under the influence of different doses of iron and aluminium coagulants in charophyte meadows, which was tested during mesocosm field experiments.

\section{Methods}

The field experiment was conducted in a shallow lake (area 13.3 ha, max depth $4.0 \mathrm{~m}$ ) located in Wielkopolska National Park (N 52¹7'43”, E 1640'5”). This lake is characterized by a dominance of charophyte meadows and a wide belt of helophytes. Eight steel constructions (open to the sediments and atmosphere; dimensions $1 \times 1 \times 2 \mathrm{~m}$ ) with walls made of polyethylene foil, transparent to sunlight, used as mesocosms. The mesocosms were placed in the gyttja bottom sediments in the littoral zone (Fig. 1) and each of them had about $1 \mathrm{~m}^{3}$ volume. This site was densely inhabited by only Chara hispida L. (approx. 50 shoots per $\mathrm{m}^{2}$ ). The embedding of mesocosm in the lake sediments (to a depth of $30 \mathrm{~cm}$ ) limited the infiltration of water to the inside and walls, reaching $20 \mathrm{~cm}$ above the water level excluding water inflow by waves. After inserting the chambers in the habitat, they were left for 1 month to allow to stabilize. Subsequently, baseline conditions were determined (day 0). The study was carried out in the peak of vegetation season (July) separately for iron coagulant - iron sulphate (2014) and aluminium coagulant - polyaluminium chloride (2015). 

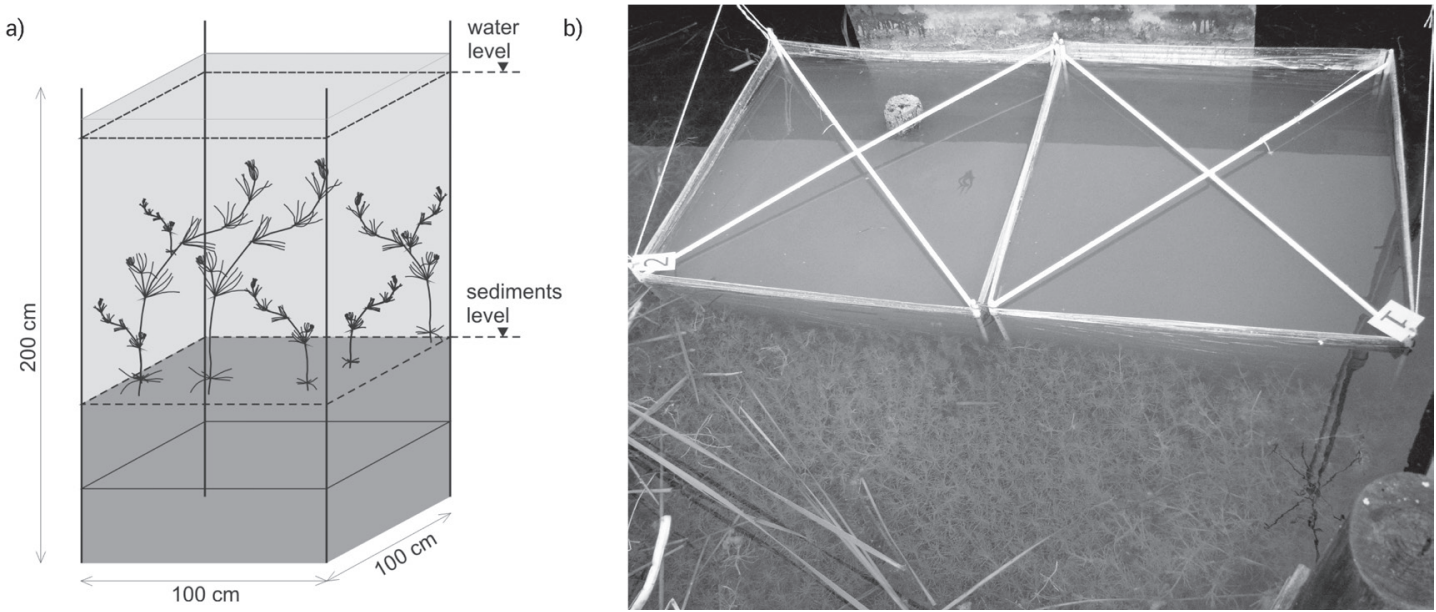

Fig. 1. Scheme of mesocosm construction a) and mesocosms in the field, immediately after coagulant application b).

The chemical characteristics of the iron coagulant, $\mathrm{Fe}_{2}\left(\mathrm{SO}_{4}\right)_{3}$ (trade name PIX 113) is: $\mathrm{pH}<1.0$, density $1500-1570 \mathrm{~kg} \mathrm{~m}{ }^{-3}$, base substance: sulphuric acid $\left(\mathrm{H}_{2} \mathrm{SO}_{4}\right)$, colour dark brown. In the case of aluminium coagulant $\left[\mathrm{Al}_{\mathrm{n}}(\mathrm{OH})_{\mathrm{m}} \mathrm{Cl}_{(3 \mathrm{n}-\mathrm{m}}\right]_{\mathrm{x}}$ (trade name PAX 18), $\mathrm{pH}=1.0$, density $1350-1370 \mathrm{~kg} \mathrm{~m}^{-3}$, base substance hydrochloric acid $(\mathrm{HCl})$, colour light yellow.

The charophyte species involved in the experiment was $C$. hispida $\mathrm{L}$. The species is widely distributed in Europe (frequent in Poland) as well as in North Africa and Asia. This is one of the largest representatives of the genus - its stem-like length can reach up to $200 \mathrm{~cm}$ [6]. In Central and Eastern Europe, it inhabits shallow eutrophic lakes and waters with slightly acidic $\mathrm{pH}$, such as peatland exploitation ponds or humic waterbodies [25-26]. C. hispida prefers alkaline and neutral waters with the calcium content between 17.0 and $167.0 \mathrm{mg}$ $\mathrm{Ca}^{2+} \mathrm{dm}^{-3}[6]$, and proves capable of growing with a wide range of available light radiation [27]. Due to habitat requirements, which are characteristic for eutrophic lakes, C. hispida communities are strongly vulnerable to restoration treatments.

The coagulants were applied one-off at the beginning of the experiment (time $\mathrm{T}_{0}$ ) in three doses: low (L), medium (M), and high $(\mathrm{H})$, in turn 50.0, 100.0 , and $200.0 \mathrm{~cm}^{3} \cdot \mathrm{m}^{-3}$, respectively. Concentrations of coagulants were determined in the laboratory experiment, where it was assumed that the lowest dose should lead to the total precipitation of suspension. Higher concentrations were a multiple of the lowest dose. To mesocosms chemicals were slowly added by a pipette (semiautomatic pipettor) and gently stirred by a hand mixer. Six of the mesocosms were used for the treatments (two for each concentration) and two of them were the control (C) trial.

The measurements and samples collection for chemical analysis were performed every day (for 3 days) and repeated after 1, 2, and 3 weeks. Measurements were done consistently at the same time of day (11:00). Dissolved oxygen (Pro Plus, Yellow Spring Instruments) and $\mathrm{pH}$ (HI 98129, Hanna Instruments) were measured in the field. The water samples for chemical analyses were preserved with sulphuric acid or nitric acid, depending on the method, directly after the collection. The following were analysed in a laboratory: total calcium and total magnesium (EDTA titrimetric method, ISO 6058:1984), sulphate $\left(\mathrm{SO}_{4}^{2-}\right.$, gravimetric method using barium chloride, ISO 9280:1990), and chloride $(\mathrm{Cl}$, silver nitrate titration with chromate indicator, ISO 9297:1989).

Dry mass of charophytes was investigated to determine a potential loss of encrustation. For this purpose, 4 individuals of $C$. hispida from each mesocosm were collected at the same time as chemical samples. After transportation to the laboratory (in closed plastic bags) they were analyzed after drying in a dryer $\left(80^{\circ} \mathrm{C}\right)$ and weighted with accuracy to $0.0001 \mathrm{~g}$.

The Shapiro-Wilk test was used to assess the normal distribution. The Levene test was applied to assess the equality of variances for groups. A two-way analysis of variance with dose and time as fixed factors (followed by Tukey multiple comparisons test) was used to check the differences between the examined elements and dry mass. All the statistical analyses were performed using Statistica 12.5 software.

\section{Results}

In both experiments, at the start the $\mathrm{pH}$ of water in mesocosms was slightly alkaline. The application of coagulants caused a temporary decrease in $\mathrm{pH}$ appropriate to the dose. The addition of iron coagulant caused a small $\mathrm{pH}$ decrease in the $\mathrm{L}$ dose $(0.88 \pm 0.01$, mean $\pm \mathrm{SD})$, and a large one in the $\mathrm{H}$ dose $(1.45 \pm 0.18)$. Meanwhile, the aluminum coagulant caused much higher reductions of $\mathrm{pH}-$ about $2.61 \pm 0.57$ in $\mathrm{L}$ dose and $4.89 \pm 0.18$ in $\mathrm{H}$ dose. Irrespective of the dose, the negative effect of acidity was reduced to the initial values $24 \mathrm{~h}$ after coagulant application (Fig. 2a-b). 

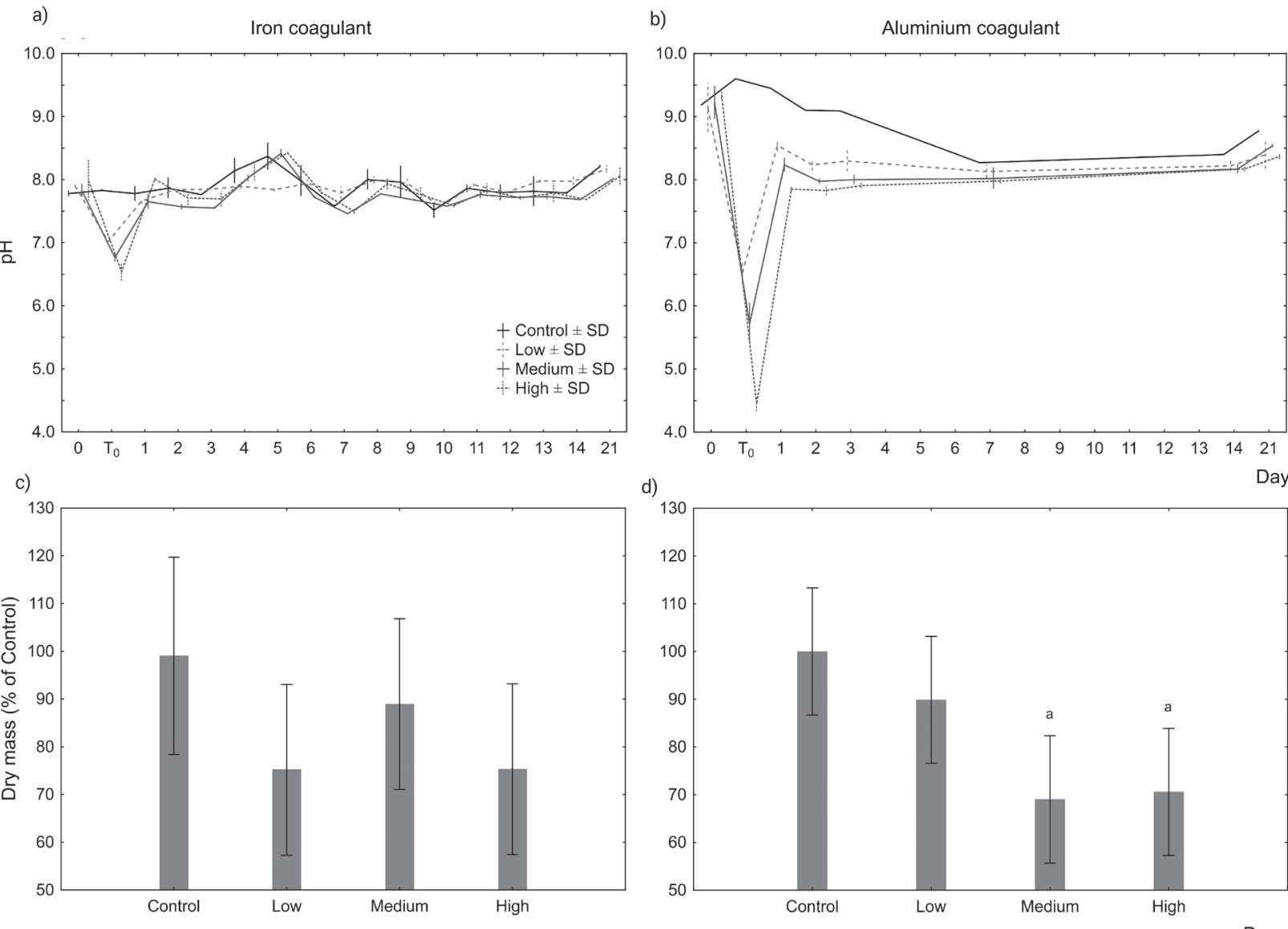

d)
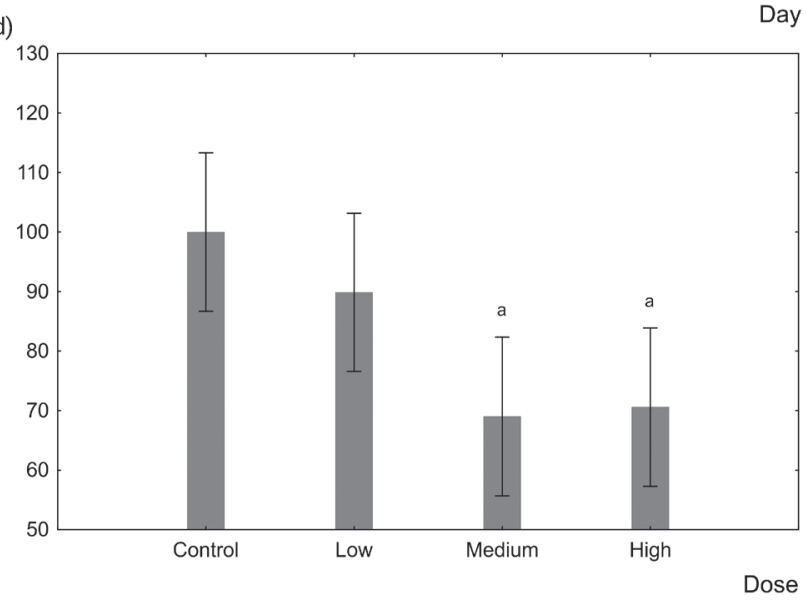

Fig. 2. Changeability of $\mathrm{pH}$ and dry mass of charophytes (as percent of control concentration) before and after application of iron coagulant (a, c) and aluminium coagulant $(b, d)$.

The dry biomass of the charophytes in mesocosms with iron coagulant was lower than in control mesocosms (Fig. 2c). Values varied between $75 \%$ in $\mathrm{L}$ and $\mathrm{H}$ dose and $90 \%$ in $\mathrm{M}$ dose compared to $\mathrm{C}$. There were no significant differences between particular treatments $\left(\mathrm{F}_{3,2}=1.75 ; \mathrm{p}=0.21\right)$. In the case of aluminum coagulant the lowest decrease was observed in L dose ( $90 \%$ compare to control). In treatments with $\mathrm{M}$ and $\mathrm{H}$ coagulant concertation dry mass was reduced to $70 \%$. Statistical analyses revealed differences $\left(\mathrm{F}_{3,2}=6.11\right.$; $\mathrm{p}<0.01$ ) between $\mathrm{C}$ chambers and $\mathrm{M}$ as well as $\mathrm{H}$ dose of coagulant (Fig. 2d). The changes were accompanied by bubbles of gases, which were tightly adhered to the charophytes thalli. In the case of $\mathrm{M}$ and $\mathrm{H}$ doses of both coagulants the amount of bubbles was so high that charophytes were even elevated above water level. As a result of bubble release, the water surface was covered by foam for 5 days.

At the beginning of each experiment the oxygen saturation of water in mesocosms was $100 \% \mathrm{O}_{2}$. After the addition of iron coagulant the oxygenation increased to max. $120 \% \mathrm{O}_{2}$ in $\mathrm{L}$ dose, min. $102 \% \mathrm{O}_{2}$ in $\mathrm{H}$ dose. In the experiment with aluminum coagulant there were no differences in oxygen saturation of water between the doses and control mesocosms.
The analysis of $\mathrm{Ca}^{2+}$ concentrations under the influence of iron coagulant showed the greatest increase in the case of $\mathrm{M}$ dose, where an increase by $15 \%$ was observed, in comparison with $\mathrm{C}$ (Fig. 3a). In $\mathrm{H}$ dose, despite higher water acidification, the value of calcium concentration was comparable to $\mathrm{C}$ and $\mathrm{L}$. Hence statistical differences were shown between $M$ dose and the other doses. The application of aluminum coagulant caused an increase in calcium concentration - linear in relation to the dose - by $40 \%$ in $\mathrm{M}$ dose and by $70 \%$ in $\mathrm{H}$ dose in comparison to control (Fig. 3b). A two-way ANOVA revealed that both the coagulant dose and time had a significant effect on $\mathrm{Ca}^{2+}$ concentration differences (Table 1). In the case of $\mathrm{Mg}^{2+}$ there were no statistically significant differences indicating the relationship between the dose and concentration of the element resulting from the application of iron coagulant (Fig. 3c). However, time was the key factor of this experiment (Table 1). Following the application of aluminum coagulant, magnesium concentrations increased significantly only in $\mathrm{H}$ dose (Fig. 3d). The dose as well as time were the differentiating factors, and to a lesser extent the interaction of both (Table 1).

The application of coagulants also caused an increase in concentration of ions constituting the base substance 
of sulphates and chlorides. An interesting fact is that the highest concentrations of $\mathrm{SO}_{4}^{2-}$ were found in $\mathrm{M}$ dose, where they were $70 \%$ higher compared with control and $40 \%$ higher than in $\mathrm{H}$ dose (Fig. 3e). In the case of aluminum coagulant, the increase in the concentrations of chlorides in $\mathrm{L}$ and $\mathrm{M}$ doses was similar $(60 \%$ in comparison to control), and noticeably higher in $\mathrm{H}$ dose (over 200\%; Fig. 3f). A statistical analysis revealed that the dose of coagulant and time were the sources of variability of $\mathrm{SO}_{4}^{2-}$ concentrations, while the variability of $\mathrm{Cl}^{-}$concentrations was due to the dose size, time, and interaction of both (Table 1).

\section{Discussion}

The coagulants applied in the experiment belong to the most common ones used in restoration treatments. Doses applied to mesocosms corresponded with the so-called 'aggressive restoration.' This type of restoration treatment results in the total elimination of phosphates, total suspended solids, and water colour after single, high-dose coagulant application [24]. This is the opposite method to 'sustainable restoration' consisting of low concentrations of coagulant application several times a year [28]. Although
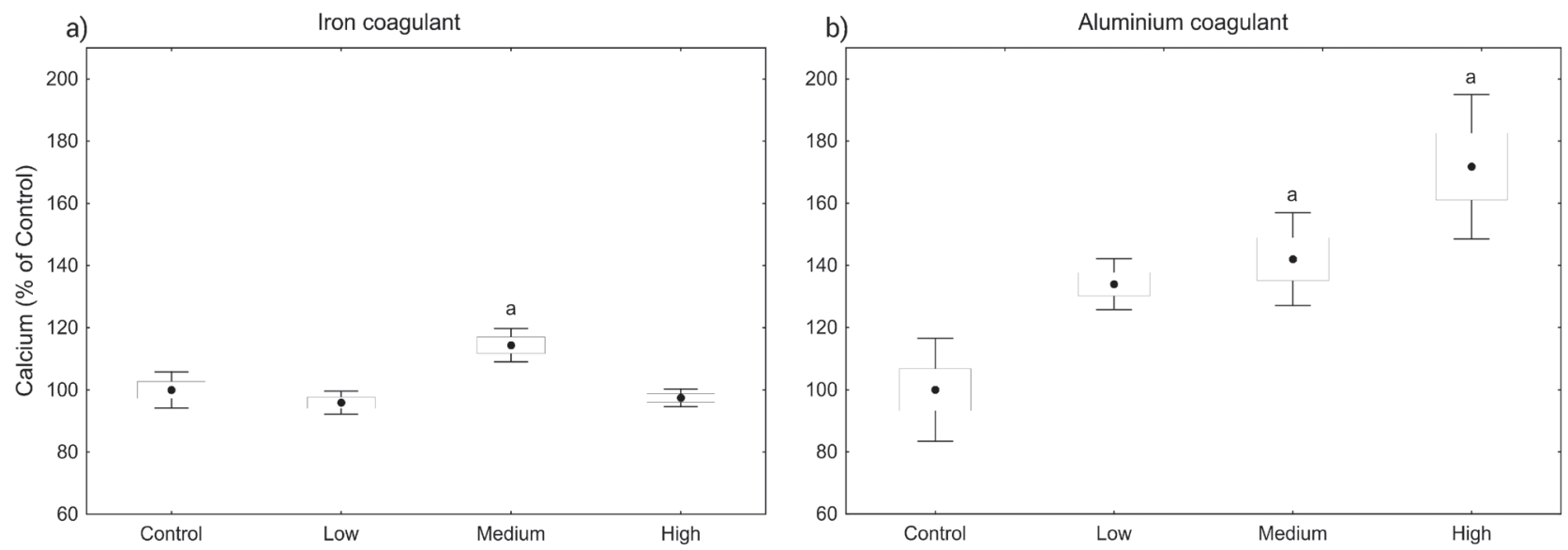

c)

d)
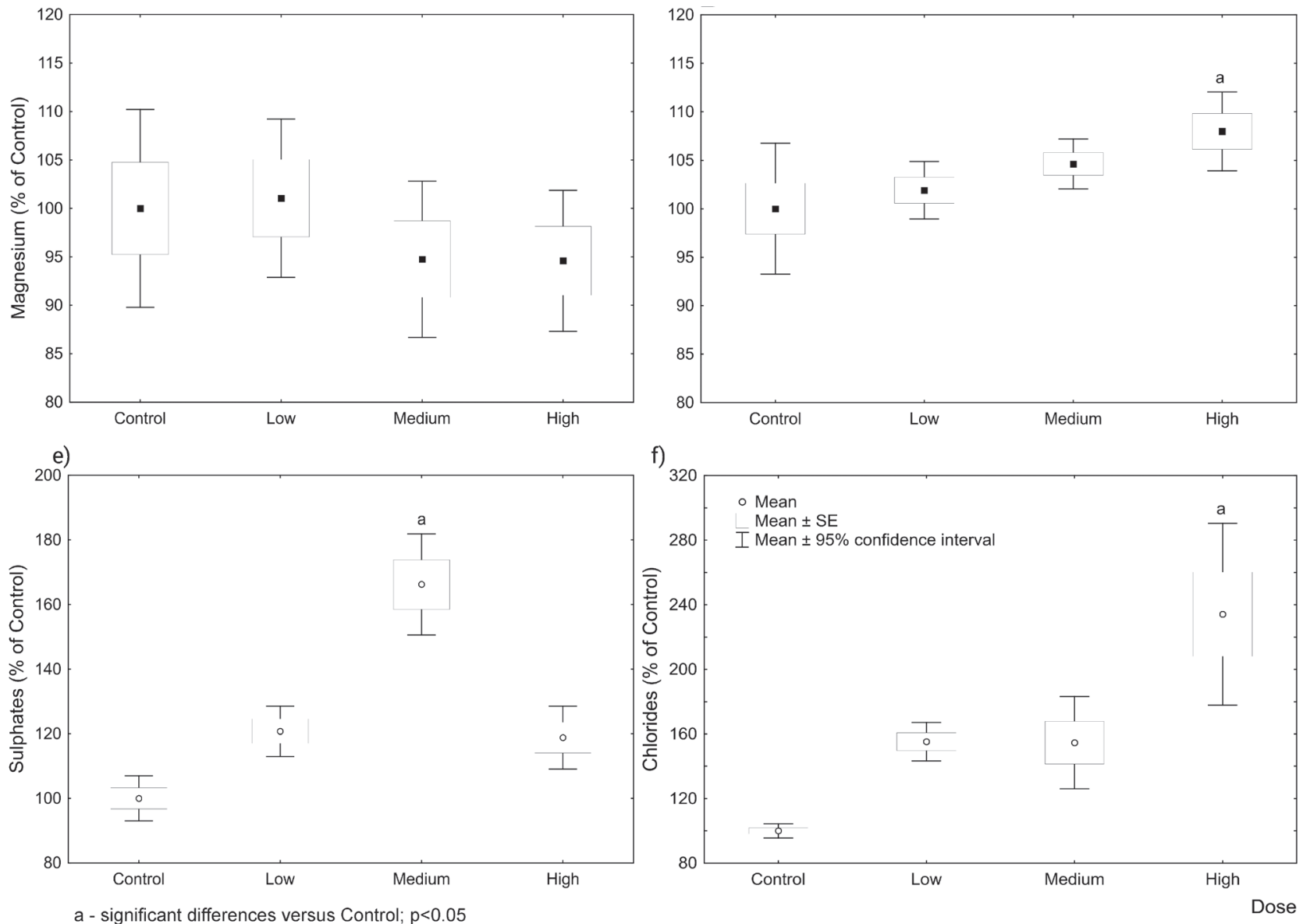

f)

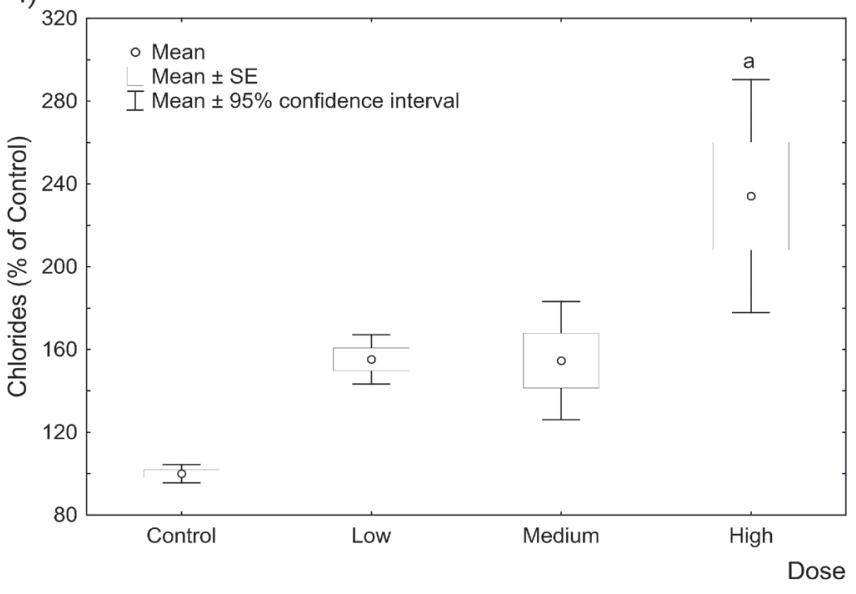

Fig. 3. Differences of ions concentrations between iron (a, c, e) and aluminium coagulant (b, d, f) doses. 
Table 1. Results of the two-way ANOVA ( $F$-ratios and $p$ values) to test for the effects of coagulant dose, experiment time, and their interaction on elements concentration.

\begin{tabular}{|c|c|c|c|c|c|c|}
\hline \multicolumn{7}{|c|}{ Iron coagulant } \\
\hline Variable & \multicolumn{2}{|c|}{$\mathrm{Ca}^{2+}$} & \multicolumn{2}{c|}{$\mathrm{Mg}^{2+}$} & \multicolumn{2}{c|}{$\mathrm{SO}_{4}{ }^{2-}$} \\
\hline & $\mathrm{F}$ & $\mathrm{p}$ & $\mathrm{F}$ & $\mathrm{p}$ & $\mathrm{F}$ & $\mathrm{p}$ \\
\hline Dose & 42.97 & $<0.000$ & 1.20 & 0.322 & 56.80 & $<0.000$ \\
\hline Time & 7.55 & $<0.000$ & 4.57 & $<0.000$ & 5.13 & $<0.000$ \\
\hline Dose $\times$ Time & 1.84 & $<0.03$ & 1.37 & 0.154 & 2.41 & $<0.002$ \\
\hline \multicolumn{7}{|c|}{ Aluminium coagulant } \\
\hline \multicolumn{7}{|c|}{$\mathrm{Ca}^{2+}$} \\
\hline Dose & 110.94 & $<0.000$ & 4.48 & $<0.02$ & 37.01 & $<0.000$ \\
\hline Time & 20.34 & $<0.000$ & 4.35 & $<0.02$ & 7.95 & $<0.000$ \\
\hline Dose $\times$ Time & 7.71 & $<0.000$ & 2.91 & $<0.03$ & 2.23 & 0.053 \\
\hline
\end{tabular}

concentrations used in the experiment seem to be high, all could be classified as commonly used in lake restoration $[29,30]$.

The phosphorus coagulants influenced calcium and magnesium concentrations, which affected Chara hispida communities. The main factor causing the changes was the decrease in $\mathrm{pH}$ determined by the coagulant concentration applied to the mesocosms. Lower $\mathrm{pH}$ caused a dissolution of charophyte encrustation, therefore releasing calcium and magnesium ions into the water. This was confirmed by decreasing the dry mass of charophytes, since encrustation can exceed even $80 \%$ of their dry weight [31]. An additional aspect causing changes in the abiotic environment was the increased concentration of ions constituting the coagulant. In the conducted experiments, acidification was neutralized within the first $24 \mathrm{~h}$ due to the reaction of hydrogen ions with calcium carbonate. Neutralization was supported by the photosynthesis process due to the increase in concentration of hydrogen carbonate ions originating from the dissolved encrustation. This was indicated by water oversaturation when $\mathrm{pH}$ changes were highest [32]. The slower pace of neutralization observed in the experiment involving polyaluminum chloride resulted from the more intensive acidification of the environment by hydrochloric acid. In natural conditions the encrustation is created as a result of $\mathrm{CO}_{2}$ uptake from bicarbonates during photosynthesis [33]. The acidification caused the dissolution of $\mathrm{CaCO}_{3}$ (2) and/or $\mathrm{MgCO}_{3}$ (3), and a $\mathrm{Ca}^{2+}$ and $\mathrm{Mg}^{2+}$ ions were released into the water. In this process $\mathrm{CO}_{2}$ is also released, which was visible as bubbles on charophytes thalli and was the reason of foam generation on water surface.

$$
\begin{aligned}
& \mathrm{CaCO}_{3}+\mathrm{H}^{+} \rightarrow \mathrm{HCO}_{3}^{-}+\mathrm{Ca}^{2+} \\
& \mathrm{MgCO}_{3}+\mathrm{H}^{+} \rightarrow \mathrm{HCO}_{3}^{-}+\mathrm{Mg}^{2+}
\end{aligned}
$$

The difference in the concentration of released calcium ions, observed in the case of iron coagulant application between $\mathrm{M}$ and $\mathrm{H}$ dose, was contrary to expectations. Higher acidification was obtained in $\mathrm{H}$ dose, and therefore the highest calcium concentrations were also expected in this dose (such an effect was obtained in the case of aluminum coagulant). An analogous situation with the concentration of $\mathrm{SO}_{4}^{2-}$ suggests that the solubility equilibrium of calcium sulphate, $\mathrm{CaSO}_{4}\left(K_{s p}=6.3 \cdot 10^{-5}\right)$, was exceeded in $\mathrm{H}$ dose of coagulant. As a consequence, the precipitation of excess calcium ions occurred due to a high supply of sulphate ions. The product of solubility calculated on the basis of concentrations of $\mathrm{Ca}^{2+}$ and $\mathrm{SO}_{4}^{2-}$ ions occurring in Medium dose after $24 \mathrm{~h}$ was lower by one order of magnitude $\left(K_{s p}=2.15 \cdot 10^{-6}\right)$. It should be underlined that a 2-fold lower dose of coagulant was used here and, consequently, lower acidification of water affecting the dissolution of encrustation occurred. As a result of weak solubility of calcium sulphate $\left(\mathrm{CaSO}_{4}\right)$, a part of the calcium budget is permanently removed from biological circulation. This type of decalcification may result in a negative calcium balance in the lake ecosystem and, as a consequence, in the disturbance or elimination of charophyte communities. In the case of aluminum coagulant we observed the increase in calcium concentration proportional to acidification. The precipitation of calcium chloride was not found due to the high solubility of the compound. Calcium ions are vital for regulating various levels of functions in plants and algae, such as electric balance between the extracellular and intracellular spaces as well as metabolic activities [34]. Apart from these functions, calcium is an essential cation, which affects chlorophyll accumulation. However, extremely increased calcium content in water (when it does not precipitate) may be a disturbance factor in the photosynthesis process for charophytes [35]. As Pełechaty et al. indicated [31], 
an average $\mathrm{CaCO}_{3}$ precipitation can be estimated as $167 \mathrm{~g} \mathrm{~m}^{-2}$. This implies that in a hypothetical situation when only $60 \%$ of encrustation is dissolved, an additional $40 \mathrm{~g}$ of $\mathrm{Ca}^{2+}$ is released into the water. However, the data indicate that the values for precipitated $\mathrm{CaCO}_{3}$ may actually be higher than the above mean and exceed $1500 \mathrm{~g} \mathrm{CaCO}_{3} \mathrm{~m}^{2}$ [36]. A larger than required amount of $\mathrm{Ca}^{2+}$ results in chlorophyll $b$ reduction and changes the chlorophyll $a: b$ ratio together with decreasing photosynthesis efficiency $[2,37]$. Moreover, thalli damage that occurred under coagulant influence decreased photosynthetic pigment concentration and impaired recovery significantly. This is particularly dangerous in the case of aluminium coagulant. Acidification leads to increased toxicity of aluminium ions, which penetrated to charophyte cells and caused severe impairment [38-39].

In the case of magnesium, the application of iron coagulant did not cause noticeable changes in its concentration since $\mathrm{MgCO}_{3}$ is more resistant to dissolution [40]. The acidification of water in the experiment was too weak to trigger the effect of the disintegration of $\mathrm{MgCO}_{3}$. Therefore, the concentration changes in time were the result of natural and relatively small fluctuations. Much higher and statistically significant changes of $\mathrm{Mg}^{2+}$ ions concentrations were observed following the application of polyaluminum chloride, particularly in high doses. This indicated the existence of high potential dissolution of $\mathrm{MgCO}_{3}$ at $\mathrm{pH}<4.5$. The fluctuations of the element concentration observed during the experiment indicated small effectiveness of the process of its precipitation. High concentrations of magnesium inhibit the process of charophyte calcification by calcium carbonate [18]. This is the result of $\mathrm{Mg}^{2+}$ binding with hydrogen carbonate ions or getting onto the growing surface of the crystal, essentially preventing further precipitation of $\mathrm{CaCO}_{3}$ [41]. Magnesium is an essential constituent of chlorophylls and therefore is regarded as an absolute requirement for green algae [42]. Increased magnesium concentration aid shoot elongation and the development of primary, secondary, and tertiary branchlets in charophytes [35]. Moreover, with the increasing $\mathrm{Mg}^{2+}$ ions content in the water, $\mathrm{Chl} b$ might increase as well, changing the $\mathrm{Chl} a: b$ ratio in an opposite way from $\mathrm{Ca}^{2+}$ [2]. Thus, the presence of both $\mathrm{Ca}^{2+}$ and $\mathrm{Mg}^{2+}$ resulted in no change in the Chl $a: b$ ratio. This is caused by antagonistic interactions neutralizing the negative effect of one element in the presence of another, hence $\mathrm{Ca}^{2+}$ effects are reduced by $\mathrm{Mg}^{2+}$ and vice versa [2]. However, in conducted experiments the situation with increasing concentrations of both $\mathrm{Ca}^{2+}$ and $\mathrm{Mg}^{2+}$ occurred only in the one particular treatment with the highest dose of aluminum coagulant. This may imply considerably greater calcium effect on charophytes under chemical restoration treatments.

Apart from iron and aluminum, $\mathrm{SO}_{4}{ }^{2-}$ and $\mathrm{Cl}^{-}$are also introduced to water with coagulants. In the experiment with iron coagulant, the highest concentration of $\mathrm{SO}_{4}^{2-}$ was observed in $\mathrm{M}$ dose, and not in $\mathrm{H}$ dose, where $\mathrm{CaSO}_{4}$ was precipitated (cf. above). In the oxygenic conditions sulphates do not have a negative influence on biota [43-44], but they intensify the secondary supply of water in phosphates from bottom sediments, and at the same time its eutrophication [45]. The content of $\mathrm{Cl}^{-}$changed adequately to the dose of aluminum coagulant, reaching the maximum in $\mathrm{H}$ dose. Similar average concentration in $\mathrm{L}$ and $\mathrm{M}$ doses demonstrated in Fig. 3e) was a result of faster elimination of $\mathrm{Cl}^{-}$in $\mathrm{M}$ than in L dose during the first week of the experiment. In the final phase, their concentrations in all mesocosms were similar to control. Chlorides, as weakly reactive, remain fully dissolved in water and only their small part is subject to sorption by bottom sediments. Meanwhile, they are the main mineral anion for plants [46]. Changes in their concentrations in conjunction with $\mathrm{pH}$ fluctuations may cause disturbances in $\mathrm{Cl}^{-}$transport at the plasma membrane in charophyte cells [47].

\section{Conclusion}

The coagulants based on strong acids, which are used in lake restoration, influence $\mathrm{Ca}^{2+}$ and $\mathrm{Mg}^{2+}$ ion concentrations. These changes have an impact on Chara hispida communities, which inhabit eutrophic lakes. The main reason for changes is the $\mathrm{pH}$ drop, which significantly changes the abiotic environment preferred by charophytes and causes disturbances in the chemical equilibrium. It was shown that polyaluminum chloride causes stronger acidification of water than iron sulphate. A high dose of iron coagulant results in the elimination of a certain amount of calcium from biological circulation, while aluminum coagulant increases the mobility of magnesium. Both processes disturb the $\mathrm{Ca}-\mathrm{Mg}$ equilibrium, which results in the disturbance of biogenic calcification and may affect charophyte metabolism and development. Treatments repeated in an amount that exceeds the environmental tolerance may disturb the whole ecosystem and cause profound changes in the abiotic environment. Therefore, applications of acid coagulants of phosphates for the purpose of improving a lake's ecological state may be dangerous for charophytes. In such a situation, the restoration effort may be diminished by a negative effect following the disappearance of underwater plant communities.

\section{Conflict of Interest}

The authors declare no conflict of interest.

\section{References}

1. BAKKER E.S., SARNEEL J.M., GULATI R.D., LIU Z., VAN DONK E. Restoring macrophyte diversity in 
shallow temperate lakes: Biotic versus abiotic constraints. Hydrobiologia 710 (1), 23, 2013.

2. ASAEDA T., SENAVIRATHNA M.D.H.J., KANEKO Y., RASHID M.H. Effect of calcium and magnesium on the growth and calcite encrustation of Chara fibrosa. Aquat. Bot. 113, 100, 2014

3. KUFEL L., KUFEL I. Chara beds acting as nutrient sinks in shallow lakes - a review. Aquat. Bot. 72 (3-4), 249, 2002.

4. LI J.Y., DENG K.Y., HESTERBERG D., XIA Y.Q., WU C.X., XU, R.K. Mechanisms of enhanced inorganic phosphorus accumulation by periphyton in paddy fields as affected by calcium and ferrous ions. Sci. Total Environ. 609, 466, 2017.

5. URBANIAK J. Estimation of carbonate and element content in Charophytes - methods of determination. Pol. J. Environ. Stud. 19 (2), 413, 2010.

6. GĄBKA M. Charophytes of the Wielkopolska Region (NW Poland): Distribution, taxonomy and autecology. Bogucki Sci. Press: Poznań, Poland, pp. 1-33, 2009.

7. PUKACZ A., PEŁECHATY M., PEŁeChAtA A. The relation between charophytes and habitat differentiation in temperate lowland lakes. Pol. J. Ecol. 61 (1), 105, 2013.

8. SOBCZYŃSKI T., JONIAK T. The variability and stability of water chemistry in deep temperate lake: Results of longterm study of eutrophication. Pol. J. Environ. Stud. 22 (1), 227, 2013.

9. ROSIŃSKA J., KOZAK A., DONDAJEWSKA R., GOŁDYN R. Cyanobacteria blooms before and during the restoration process of a shallow urban lake. J. Environ. Manage. 198 (1), 340, 2017.

10. DUNALSKA J.A., GROCHOWSKA J., WIŚNIEWSKI G., NAPIÓRKOWSKA-KRZEBIETKE A. Can we restore badly degraded urban lakes? Ecol. Eng. 82, 432, 2015.

11. SOBCZYŃSKI T., JONIAK T., PRONIN E. Assessment of the multi-directional experiment of restoration of Lake Góreckie (western Poland) with particular focus to oxygen and light conditions: first results. Pol. J. Environ. Stud. 21 (4), 1025, 2012

12. DUNALSKA J.A., WIŚNIEWSKI G. Can we stop the degradation of lakes? Innovative approaches in lake restoration. Ecol. Eng. 95, 714, 2016.

13. ZAMPARAS M., ZACHARIAS I. Restoration of eutrophic freshwater by managing internal nutrient loads. A review. Sci. Total Environ. 496, 551, 2014.

14. FRAME J.L., JONES J.I., ORMEROD S.J., SADLER J.P., LEDGER M.E. Biological barriers to restoration: testing the biotic resistance hypothesis in an upland stream recovering from acidification. Hydrobiologia 777 (1), 161, 2016.

15. KLIMASZYK P., RZYMSKI P., PIOTROWICZ R., JONIAK T. Contribution of surface runoff from forested areas to the chemistry of a through-flow lake. Environ. Earth Sci. 73 (8), 3963, 2015.

16. RAVEN J.A., SMITH F.A., WALKER N.A. Biomineralization in the Charophyceae sensu lato. In Biomineralization in lower plants and animals; Leadbeater B.S.C., Riding R., Eds., Oxford University Press: Oxford, United Kingdom, pp. 400, 1986.

17. KUFEL L., STRZAŁEK M., BIARDZKA E. Site- and species-specific contribution of charophytes to calcium and phosphorus cycling in lakes. Hydrobiologia 767 (1), 185, 2016.

18. CICERONE D.S., STEWART A.J., ROH Y. Diel cycles in calcite production and dissolution in a eutrophic basin. Environ. Toxicol. Chem. 18 (10), 2169, 1999.
19. KAWAHATA C., YAMAMURO M., SHIRAIWA Y. Changes in alkaline band formation and calcification of corticated charophyte Chara globularis. SpringerPlus 2, 85, 2013.

20. SOULIÉ-MÄRSCHE I., GARCÍA A. Gyrogonites and oospores, complementary viewpoints to improve the study of the charophytes (Charales). Aquat. Bot. 120, 7, 2015.

21. COLETTA P., PENTECOST A., SPIRO B. Stable isotopes in charophyte incrustations: relationships with climate and water chemistry. Palaeogeogr. Palaeoclimatol. Palaeoecol. 173 (1-2), 9, 2001.

22. WANG H., NI L., YU D. Significance of $\mathrm{HCO}^{3-}$ alkalinity in calcification and utilization of dissolved inorganic carbon in Chara vulgaris. Aquat. Biol. 26, 169, 2017.

23. IMMERS A.K., VENDRIG K., IBELINGS B.W., VAN DONK E., TER HEERDT G.N.J., GEURTS J.J.M., BAKKER E.S. Iron addition as a measure to restore water quality: Implications for macrophyte growth. Aquat. Bot. 116, 44, 2014

24. RYBAK M., JONIAK T., GĄBKA M., SOBCZYŃSKI T. The inhibition of growth and oospores production in Chara hispida L. as an effect of iron sulphate addition: conclusions for the use of iron coagulants in lake restoration. Ecol. Eng. 105, 1, 2017.

25. URBANIAK J. Analysis of morphological characters of Chara baltica, C. hispida, C. horrida, and C. rudis from Europe. Plant Syst. Evol. 286 (3), 209, 2010.

26. URBANIAK J., GĄBKA M. Polish Charophytes: An illustrated guide to identification. Wrocław Univ. Press: Wrocław, Poland, pp. 60-61, 2014.

27. ANDREWS M., BOX R., MC INROY S., RAVEN J.A. Growth of Chara hispida. II. Shade adaptation. J. Ecol. 72 (3), 885, 1984.

28. ROSIŃSKA J., KOZAK A., DONDAJEWSKA R., KOWALCZEWSKA-MADURA R., GOŁDYN R. Water quality response to sustainable restoration measures Case study of urban Swarzędzkie Lake. Ecol. Indic. 84, 437, 2018

29. BAKKER E.S., VAN DONK E., IMMERS A.K. Lake restoration by in-lake iron addition: a synopsis of iron impact on aquatic organisms and shallow lake ecosystems. Aquat. Ecol. 50 (1), 121, 2016.

30. ORIHEL D.M., SCHINDLER D.W., BALLARD N.C., WILSON L.R., VINEBROOKE R.D. Experimental iron amendment suppresses toxic cyanobacteria in a hypereutrophic lake. Ecol. Appl. 26 (5), 1517, 2016.

31. PEŁECHATY M., PUKACZ A., APOLINARSKA K., PEŁECHATA A., SIEPAK M. The significance of Chara vegetation in the precipitation of lacustrine calcium carbonate. Sedimentology 60 (4), 1017, 2013.

32. DE MONTETY V., MARTIN J.B., COHEN M.J., FOSTER C., KURZ M.J. Influence of diel biogeochemical cycles on carbonate equilibrium in a karst river. Chem. Geol. 283 (1-2), 31, 2011.

33. PUKACZ A., PEŁECHATY M., FRANKOWSKI M., KOWALSKI A., ZWIJACZ-KOSZAŁKA K. Seasonality of water chemistry, carbonate production, and biometric features of two species of Chara in a shallow clear water lake. Sci. World J. 167631, 2014.

34. EDEL K.H., MARCHADIER E., BROWNLEE C., KUDLA J., HETHERINGTON A.M. The evolution of calcium-based signalling in plants. Curr. Biol. 27 (13), R667, 2017.

35. GOMES P.I.A., ASAEDA T. Impact of calcium and magnesium on growth and morphological acclimations 
of Nitella: implications for calcification and nutrient dynamics. Chem. Ecol. 26 (6), 479, 2010.

36. PUKACZ A., PEŁECHATY M., FRANKOWSKI M. Depth-dependence and monthly variability of charophyte biomass production: consequences for the precipitation of calcium carbonate in a shallow Chara-lake. Environ. Sci. Pollut. Res. 23, 22433, 2016.

37. SIDDIQUI M.H., AL-WHAIBI M.H., SAKRAN A.M., BASALAH M.O., ALI H.M. Effect of calcium and potassium on antioxidant system of Vicia faba L. under cadmium stress. Int. J. Mol. Sci. 13 (6), 6604, 2012.

38. RYBAK M., JONIAK T., GĄBKA M., SOBCZYŃSKI T., RATAJCZAK I. Ecological implications the use of chemical methods in lakes restoration: Impact of aluminium coagulants on stoneworts. In Materials of International Multidisciplinary Scientific GeoConferenceSGEM 2, 271, 2016.

39. RYBAK M., KOŁODZIEJCZYK A., JONIAK T., RATAJCZAK I., GĄBKA M. Bioaccumulation and toxicity studies of macroalgae (Charophyceae) treated with aluminium: Experimental studies in the context of lake restoration. Ecotoxicol. Environ. Saf. 145, 359, 2017.

40. MÜLLER G., IRION G., FÖRSTNER U. Formation and diagenesis of inorganic $\mathrm{Ca}-\mathrm{Mg}$ carbonates in the lacustrine environment. Naturwissenschaften 59 (4), 158, 1972.
41. SIONG K., ASAEDA T. Effect of magnesium on charophytes calcification: implications for phosphorus speciation stored in biomass and sediment in Myall Lake (Australia). Hydrobiologia 632 (1), 247, 2009.

42. VYMAZAL J. Algae and element cycling in wetlands. CRC Press, 1994.

43. VAN DER WELLE M.E.W., CUPPENS M., LAMERS L.P.M., ROELOFS J.G. Detoxifying toxicants: interactions between sulphide and iron toxicity. Environ. Toxicol. Chem. 25 (6), 1592, 2006.

44. LAMERS L.P.M., GOVERS L.L., JANSSEN I.C.J.M., GEURTS J.J.M., VAN DER WELLE M.E.W., VAN KATWIJK M.M., VAN DER HEIDE T., ROELOFS J.G.M., SMOLDERS A.J.P. Sulfide as a soil phytotoxin - a review. Front. Plant Sci. 4, 268, 2013.

45. CIRKEL D.G., VAN BEEK C.G.E.M., WITTE J.P.M., VAN DER ZEE S.E.A.T.M. Sulphate reduction and calcite precipitation in relation to internal eutrophication of groundwater fed alkaline fens. Biogeochemistry 117 (2-3), 375, 2014.

46. PARIHAR P., SINGH S., SINGH R., SINGH V.P., PRASAD S.M. Effect of salinity stress on plants and its tolerance strategies: a review. Environ. Sci. Pollut. Res. 22 (6), 4056, 2015.

47. SANDERS D. Physiological control of chloride transport in Chara corallina: II. The role of chloride as a vacuolar osmoticum. Plant Physiol. 68 (2), 401, 1981. 